\title{
Effects of groundwater regulation on aquifer-system compaction and subsidence in the Houston-Galveston Region, Texas, USA
}

\author{
M. J. Turco and A. Petrov \\ Harris-Galveston Subsidence District, Friendswood, Texas, USA \\ Correspondence to: M. J. Turco (mturco@subsidence.org) \\ Published: 12 November 2015
}

\begin{abstract}
Subsidence has been a primary concern in the Houston area for many years. Since 1906, about $4 \mathrm{~m}$ of subsidence has occurred in the coastal areas, with a broad area of about $2 \mathrm{~m}$ of subsidence existing today throughout most of the Houston Area. In 1975, as a result of area residents and local governments becoming increasingly alarmed by the continued impact of subsidence on economic growth and quality of life in the region, the Harris-Galveston Subsidence District was created by the 64th Texas Legislature as an underground water conservation district with the mission to provide for the regulation of the withdrawal of groundwater to control subsidence. Over its nearly 40 years of existence, the District has developed substantial data sets providing the foundation for its regulatory plan. The District's regulatory plan allows groundwater users an amount of annual groundwater based on a percentage of an individual permitee's total water demand. The management of the groundwater resources within the District has involved significant coordination with regional ground and surface water suppliers; ongoing interaction with other state and local regulatory bodies; analysis of accurate and up to date predictions on water usage; the enforcement of disincentives to those who rely too heavily on groundwater and a commitment to practicing and promoting water conservation. Areas nearest the Gulf of Mexico coast have completed the conversion to alternative (other than groundwater) water sources, consequently the effective stress on the aquifer has decreased and subsidence rates have been reduced. Areas within the District further inland are currently proceeding through the conversion process, and subsidence has continued in those areas as development of the groundwater resources has continued.
\end{abstract}

\section{Introduction}

Subsidence has been a concern in the Houston, Texas area throughout most of recent history. The U.S. Geological Survey first documented the correlation between shallow fluid withdrawal and subsidence in 1929 at the Goose Creek Oilfield near Baytown, Texas just southeast of Houston (Pratt and Johnson, 1926). Following that revelation, the area continued to develop on groundwater, water-levels in aquifer declined, and subsidence continued.

The occurance of subsidence in a coastal area prone to tropical weather can have serious consequences including loss of property and loss of life. About $4 \mathrm{~m}$ of subsidence has occurred along parts of the coastal community near Houston and Galveston, TX. These areas have seen entire develop- ments inundated by the Gulf of Mexico. There has also been evidence of infrastructure damage as a result of subsidence in the area including damage to homes and water infrastructure.

\section{Hydrogeology}

There are three primary aquifers comprising the Gulf Coast aquifer system best categorized in relative terms as "shallow and younger" sediments and "deep and older" sediments. The uppermost Chicot and underlying Evangeline aquifers are hydraulically connected and comprise the younger and shallow sediments of the system. The regionally persistent Burkeville Confining unit is stratigraphically positioned between the Evangeline and the deeper and older Jasper aquifer (Kasmarek et al., 2014). The lowermost unit of the system is 
the Miocene-age Catahoula confining system which contains the Catahoula Sandstone (Baker Jr., 1979). Through time, geologic and hydrologic processes created these accretionary sediment wedges of clay and other fine-grained clastic material more than $2300 \mathrm{~m}$ thick at the coast (Chowdhury and Turco, 2006; Baker Jr., 1979). The shallow and young sediments of the Chicot and Evangeline aquifer are the most concern when considering the potential for clay-compaction and resulting land surface subsidence.

\section{Water use}

Prior to the creation of the Harris-Galveston Subsidence District, the Houston region had relied mostly on groundwater for municipal, industrial and agricultural water supply. This reliance on groundwater coupled with the rapid development and population growth of the city of Houston led to substantial groundwater level declines and subsidence. The subsidence that occurred as a result of the increased groundwater use led to significant outcry from many in the local community and led to the creation of the HGSD by the State of Texas in 1975.

Regulating the use of groundwater is an effective measure to minimize active subsidence and prevent areas from subsiding in the future. The HGSD regulates groundwater as a percentage of the areas total water demand which allows continued growth of the area while still combating the issue of subsidence. The District began immediately focusing on those areas, currently referred to as Area 1, nearest the Gulf of Mexico, in perilous proximity to frequent tropical storms, hurricanes, and storm surge, requiring those areas to convert to $90 \%$ alternative water as soon as possible. Subsequently, conversion to $80 \%$ alternative supply occurred in Area 2 and in 2035 Area 3 will reach a similar conversion ratio. Beginning in 1976 and continuing through 2014, the percentage of groundwater used with respect to the total water demand of the area has decreased. In 1976 about 63000 hectare meter (ha $\mathrm{m}$ ) of water were sourced from groundwater with a total water demand at that time of $103000 \mathrm{ham}$. Whereas in 2014 about 26500 ham of water were sourced from groundwater with a total water demand of about 129000 ham (Fig. 1). In 2014, groundwater accounts for about $21 \%$ of the total water demand within the District, a dramatic change over the 40-year history of groundwater regulation in the area.

\section{Impact of changes in water use on subsidence}

As water use has changed in the Houston area, groundwaterlevels have risen in areas one and two and subsidence rates have slowed considerably. The HGSD operates a network of about 80 GPS subsidence monitoring stations (Fig. 2) throughout the area along with a network of 13 extensometers operated by the USGS to monitor the impact of changes in water use on subsidence in the area. The HGSD network

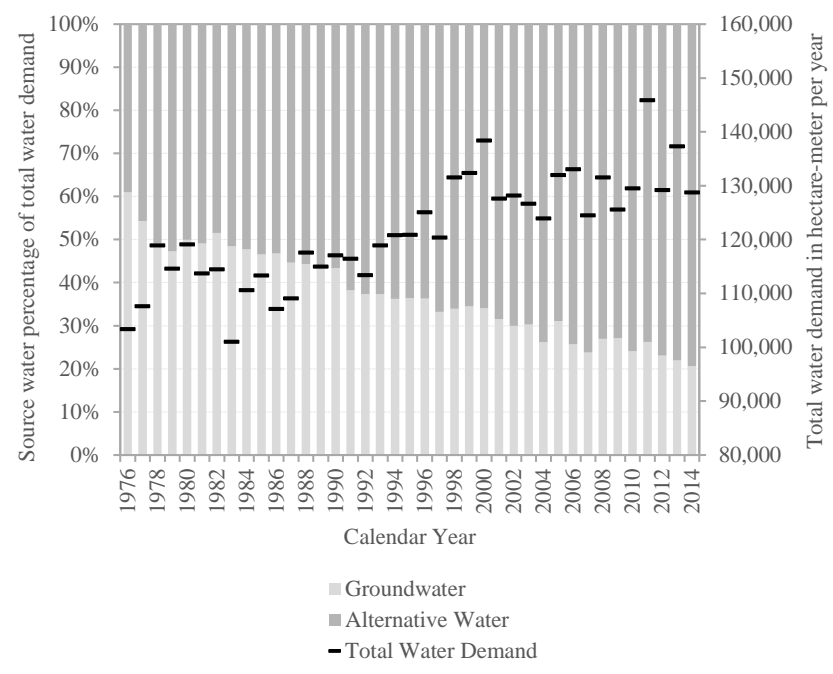

Figure 1. Groundwater and alternative source water percentage and total water demand, 1976-2014, Harris-Galveston Subsidence District, Texas, USA.

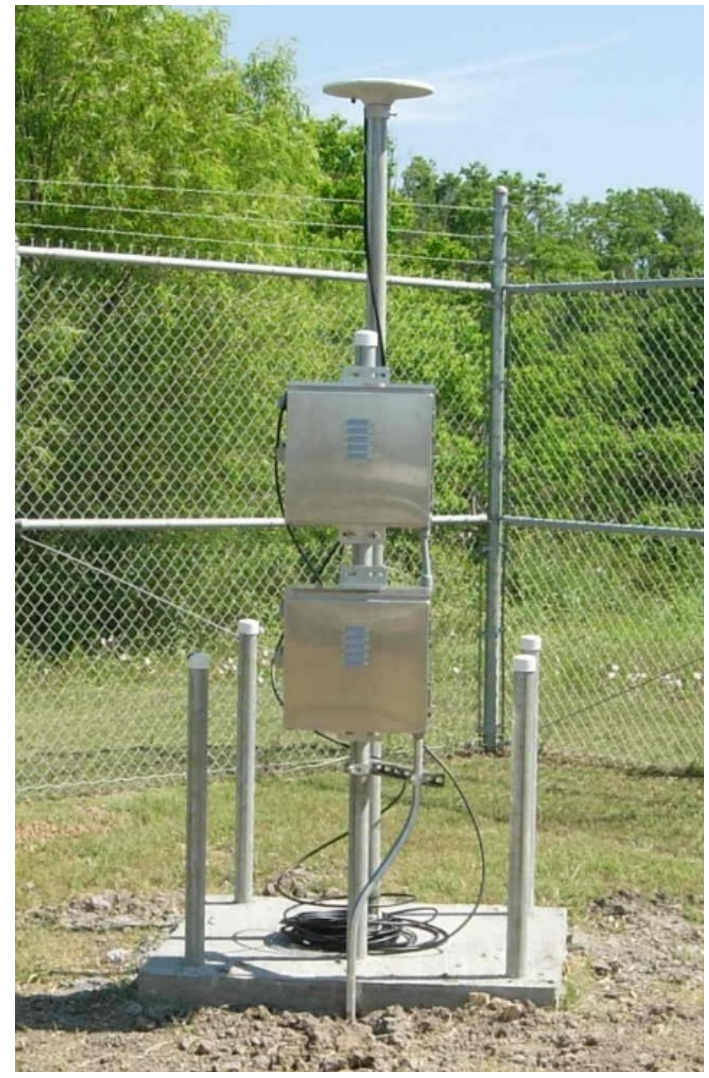

Figure 2. Subsidence monitoring station located near Texas City, TX, USA.

consists of continuously operating and periodically operating GPS stations equipped with real-time global positioning system receivers that are post-processed, determining a relative change in ellipsoid height of the monitoring station refer- 


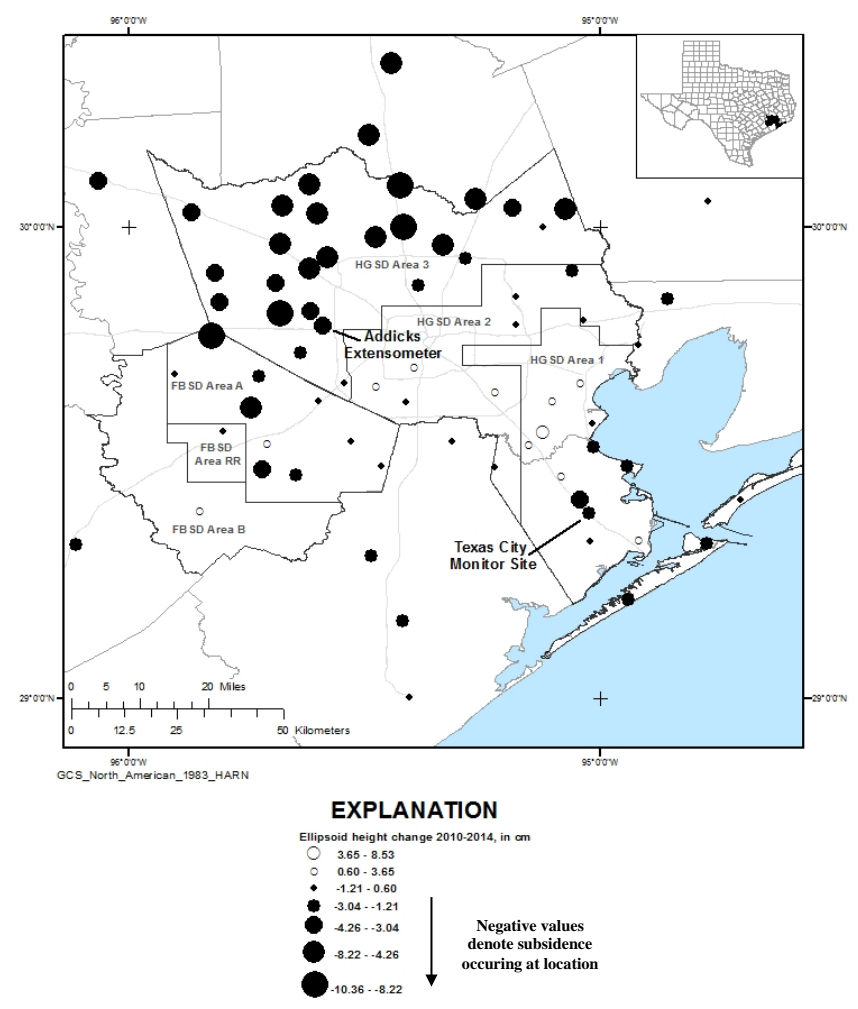

Figure 3. Observed change in ellipsoidal height calculated (Zilkoski et al., 2003) at GPS monitoring stations from 2010 to 2014, Houston area, Texas.

enced to one of the stable extensometer benchmarks at depth (Zilkoski et al., 2003).

Generally, the network shows a good correlation between measured water-levels and observed subsidence. Figure 3 shows distribution of ellipsoidal height change from 2010 to 2014, generally showing the area of highest occurrence and magnitude of subsidence occurring in Area 3, currently not fully converted to alternative water.

The Addicks extensometer is located in Area 3 and is currently the most active extensometer. Since 1975, nearly $115 \mathrm{~cm}$ of clay-compaction has occurred (Fig. 4). From late in 2010 through 2012, the Houston area experienced a prolonged drought, resulting in the highest total water demand for the area on record. Consequently, subsidence rates increased in areas one, which had not seen appreciable subsidence occur in recent history (Fig. 3).

\section{Conclusions}

The Gulf Coast aquifer system in the Houston area is uniquely susceptible to clay-compaction and subsidence due to its aquifer composition and large amounts of historical groundwater withdrawal. Changes in water use due to groundwater regulation and the conversion of groundwater users from groundwater to alternative source waters has re-
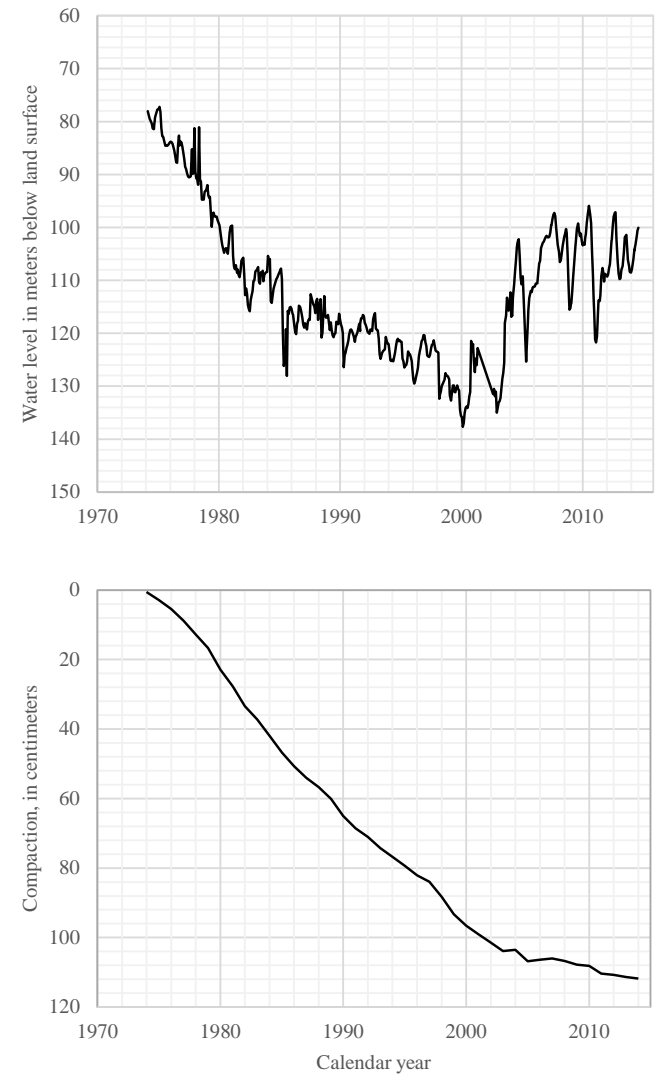

Figure 4. Water-level and cumulative compaction at the Addicks extensometer located in Harris Galveston Subsidence District Regulatory Area 3, Houston, Texas, USA, 1974-2015.

sulted in groundwater levels above the historical minimum and minimized subsidence in coastal areas. Local collaboration between the regulatory and regulated communities is absolutely necessary in coordinating the conversion from one source water to another. Considering the variability in water demand as it relates to climatic change, on-going monitoring of water-level and land surface subsidence is required to adequately gage the aquifer's response to changes in water-use.

Acknowledgements. The authors wish to thank Robert Thompson, Kevin Ebrom, Mike Chrismer, and Greg Lackey of the HarrisGalveston Subsidence District for their assistance in the preparation of this paper and the USGS Texas Water Science Center for their continued cooperation in the groundwater and subsidence research in the Houston area. Additionally, this information would not be available without the collaboration of numerous regional water providers such as the City of Houston and the North and West Harris County Regional Water Authorities. 


\section{References}

Baker Jr., E. T.: Stratigraphic and hydrogeologic framework of part of the Coastal Plain of Texas, Texas Department of Water Resources, USA, Report 236, 43 pp., 1979.

Chowdhury, A. H. and Turco, M. J.: Geology of the Gulf Coast aquifer, Texas, chap. 2, in: Aquifers of the Gulf Coast of Texas, edited by: Mace, R. E., Davidson, S. C., Angle, E. S., and Mullican, W. F., Texas Department of Water Resources, USA, Report 289, 101 pp., 2006.

Kasmarek, M. R., Johnson, M. R., and Ramage, J. K.: Water-level altitudes 2014 and water-level changes in the Chicot, Evangeline, and Jasper aquifers and compaction 1973-2013 in the Chicot and Evangeline aquifers, Houston-Galveston region, Texas, U.S. Geological Survey Scientific Investigations Map 3308, pamphlet, 16 sheets, scale $1: 100000$, available at: http://dx.doi.org/10. 3133/sim3308, last access: 14 July 2015, 2014.
Pratt, W. E. and Johnson D. E.: Local subsidence of the Goose Creek oil field, The University of Chicago Press, The Journal of Geology, 34, 577-590, 1926.

Zilkoski, D. B., Hall, L. W., Mitchell, G. J., Kammula, V., Singh, A., Chrismer, W. M., and Neighbors, R. J.: The Harris-Galveston Coastal Subsidence District/National Geodetic Survey Automated GPS Subsidence Monitoring Project, in: U.S. Geological Survey Subsidence Interest Group Conference, Proceedings of the Technical Meeting, Galveston, Texas, 27-29 November 2001, edited by: Prince, K. R. and Galloway, D. L., U.S. Geological Survey, Open-File Report 03-308, 162 pp., 2003. 